\title{
Effects of Spondias mombin $l$. on milk composition of lactating West African Dwarf (WAD) ewes
}

\author{
Oguike M. A. and M. E. Udeh \\ Department of Animal Production, Michael Okpara, University of Agriculture, Umudike, P.M.B. 7267, \\ Umuiahia, Abia State, Nigeria.
}

Corresponding Author: Dr. M.A. Oguike, (E-mail: maoguike2000@yahoo.com)

\section{Abstract}

A study was conducted to investigate the effects of Spondias mombin on milk composition using milk from twelve lactating West African dwarf (WAD) ewes. The lactating ewes were assigned to two treatment groups of six ewes per group, designated $T 1$ and $T 2$ representing control and trial group, respectively. The ewes in T2, the trial group were fed Spondias mombin L. post partum while those in $T 1$ the control were not fed Spondias mombin. Colostrum samples were collected from each ewe the first four days following parturition while normal milk was sampled for analysis after two weeks of lambing through 12 weeks of lactation. The constitutents studied were lactose, milk protein, butterfat, ash, total solids and solid non-fat. Results showed that the colostrums of ewes fed $S$. mombin had significantly higher $(P<0.05)$ total solids, and solids not fat contents of 18.34 and $11.31 \%$ respectively, than those of the control ewes which were 17.32 and $10.35 \%$, respectively. The other constituents of colostrums of the different groups were not significantly different $(P>0.05)$. At week 2 of lactation, lactose (3.98\%) and ash (0.98\%) concentrations of normal milk of treated ewes were significantly higher $(P<0.05)$ than those of the control ewes for lactose $(3.74 \%)$ and ash $(0.65 \%)$. Also by the $12^{\text {th }}$ week of lactation, ash contents of the two treatments were significantly different $(P<0.05)$ with $T 2$ having higher value.There were no significant differences $(P>0.05)$ in the normal milk compositions of both groups in weeks 4,6,8 and 10. These results suggest that feeding $S$. mombin to lactating ewes could be useful in improving on the milk composition of WAD ewes and has no adverse effects on their general health and performance.

Key words: Milk composition, Lactation, WAD ewes, Spondias mombin $L$

\section{Introduction}

Milk is a complex fluid composed of several phases that can be separated by centrifugation into a cream layer, an aqueous phase and a two phase pellet (Neville, 1995). It is an emulsion of fat in a watery solution of sugars and mineral salts with proteins in a colloidal suspension (O'Mahony and Peters, 1987). It is the sole source of nutrients for most young mammals for a length of time, which vary with species. It contains such nutrients as lactose, which supplies energy, protein for growth and maintenance of 
all cells of the body, fats and flavour, vitamins and minerals.

Colostrum is the first set of milk from parturient mammals 3-4 days post partum. Colostrums differ from normal milk in composition. It is also fortified with antibodies, which help to protect the young against diseases and infection. Ibeawuchi et al (2003) reported mean colostrum values of total solids (TS), fat, protein, solid-non-fat (SNF) ash and energy as $14.96 \%, 8.58 \%, 5.64 \%, 6.37 \%, 0.93 \%$ and $3.2 \mathrm{MJ} / \mathrm{KG}$. respectively, in Sahelian goats. These values are higher than what was obtained for mature milk, which they reported at $13.18 \%$, $7.52 \%, 4.81 \%, 0.76 \%, 5.66 \%$ and $2.79 \mathrm{MJ} / \mathrm{kg}$, respectively. In a comparative study of the constituents of cattle, sheep and goat milk, Ahamefule et al (2003) reported that sheep milk contains higher percentage total solids than cow and goat milk. WAD sheep equally produce milk of significantly higher butter fat content than either of white Fulani cow or WAD goat.

Different parts of the $S$. mombin (yellow mombin, hog plum) have been found to be useful. The leafy branches are used in cases of dystocia and retained placenta, in humans and livestock (Okafor and Lamb, 1994). It is also used as an aphrodisiac in man (Burkill, 1985). Mexicans cook the young leaves as greens and also in expulsion of calcifications from the bladder (Morton, 1987). Oguike and Udeh (2008) reported that Spondias mombin L. (Hog plum), can be used by local farmers to improve on the milk yield of the lactating WAD ewes. They further observed that it could be said to have a wide safety margin for the lactating ewe. The objective of the present study was to determine the effects of $S$ mombin on milk composition of lactating WAD ewes with a view to investigating its usefulness in the feeding of lactating ewes.

\section{Materials and Methods}

Location of study

The experiment was conducted at the Sheep and Goat Unit of Teaching and Research farm of Michael Okpara University of Agriculture, Umudike, near Umuahia, Abia State of Nigeria. Umudike bears the co-ordinate of $05^{\circ} 28^{\prime}$ North and lies: at an altitude of 122 meter above sea level. It is located within the tropical rain forest zone and an annual rainfall of about $2177 \mathrm{~mm}$ characterizes the environment. The relative humidity ranges form $50-90 \%$. The monthly ambient temperature ranges from $17^{\circ} \mathrm{C}$ to $36^{\circ} \mathrm{C}$. The warmest month of the year is March, with an average temperature of $22-30^{\circ} \mathrm{C}$ (NRCRI Metrological Centre Umudike).

\section{Management of experimental animals}

At the start of the experiment, twelve (12) mature WAD ewes, weighing $12-16 \mathrm{~kg}$, aged 2-3years, were used for the study. The twelve ewes were randomly selected from the University flock. The experimental animals were quarantined in the quarantined house for a period of 4 weeks during which they were treated against ecto and endoparasites, and equally vaccinated against pestes 
de petit ruminante (PPR) and finally certified healthy by a Veterinarian. The ewes were then transferred to the breeding pens. Forage was cut and fed to them every morning and fresh water supplied ad libitum. The ewes were also placed on a supplementary concentrate diet $(1 \mathrm{~kg} / \mathrm{ewe})$ made up of maize offal, wheat offal, groundnut cake, palm kernel cake, bone meal and table salt. The crude protein content of the concentrate diet was $13 \%$. A proven ram was introduced into the flock for breeding and allowed for a period of two weeks, after which they got pregnant (ram effect) and the ram was removed. Pregnancy diagnosis was done by linear measurement of changes in udder size and non return to oestrus. After lambing, freshly cut Spondias mombin was introduced to the ewes in the treated group, at the rate of $1 \mathrm{~kg}$ per ewe, in addition to the concentrated and forage previously fed. Sponidas mombin was given to the ewes the night before the milking after taking away the remaining forage that was given in the morning, while allowing the forage for the ewes in the control group to remain till the next morning of milk collection.

\section{Experimental Procedures}

Following pregnancy confirmation, the ewes were divided into two groups; control and treatment groups, designated $T_{1}$ and $T_{2}$, respectively with each group made up of 6 ewes.

\section{Milk collection and Sampling}

Colostrum samples from each ewe were collected by hand milking into sample bottles on the third day of lambing and immediately analyzed for lactose. The rest of the colostrum samples were stored at $-5^{\circ} \mathrm{C}$ in a deep freezer for further analysis.

Milk collection commenced after 2 weeks of lambing. The 2 weeks post partum was to ensure that lambs got enough nourishment at that critical period of their life. Prior to the days of milk collection, lambs were separated from their mothers the night before the milking, and fed artificial milk using feeding bottles. The ewes were then milked the next morning. The milk samples were than fed back to the lambs after removal of $10 \mathrm{ml}$ of milk sample required for determination of milk constituents. Milk collection and sampling continued three time per week until twelve weeks of lactation.

\section{Milk Analysis}

Chemical analysis was carried out on the milk samples to determine the percentage composition of the different milk constituents. Analysis of milk samples was done bi-weekly on the different samples of milk until the twelfth week of lactation. Milk lactose was determine immediately after milk collection, and the rest were stored at $-5^{\circ} \mathrm{C}$ in a deep freezer for analysis of milk protein, butterfat, ash, total solids and solids non-fat. Lactose was analysed using the phenol colorimetric method. Total solids were determined gravimetrically (AOAC 1990). Ash content of milk was determined by the furnace incineration method of Pearson (1977). The crude protein content $\left(\mathrm{N}_{2} \times 6.38\right)$ was determined by the Kjedahl method. Butterfat content was 
estimated using the Rose-Gottlieb's method (Pearson, 1977). Solids not-fat was calculated by subtracting percentage fat value from the total solid values for each milk sample. Metabolizable energy (ME) in $\mathrm{MJ} / \mathrm{kg}$ was determined by the methods of M.A.F.F. (1975).

\section{Statistical Analysis}

The data generated were analyzed using the independent student's t-test.

\section{Result and Discussion}

\section{Colostrum composition}

Constituents of colostsrums in control and treated S. mombin - fed groups are presented in Table

1. The total solids, and solids not fat content of the colostsrums of treated ewes were 18.34 and $11.31 \%$ respectively, and were significantly higher $(P<0.05)$ than those of the control ewes which were 17.32 and $10.35 \%$ respectively.

Although protein, lactose and ash were not significantly different ( $\mathrm{P}>0.05$ ), they were numerically higher in the colostrums of the ewes in the treated group than the control group. Energy and butterfat of the colostrums were approximately numerically equal in both groups. Higher energy value of colostrums composition is expected to contribute to better performance of lambs. Thus, it is likely that the offspring from the ewes fed spondias mombin may have performed better than the control group.

\section{Composition of normal milk}

In week 2 of lactation, a significantly higher difference $(\mathrm{P}<0.05)$ was observed in lactose concentration of milk of treated ewes $(3.98 \%)$ than in that of the control ewes which was (3.74\%). Also in week 2 of lactation, ash content of milk of ewes in the treated group was $(0.98 \%)$ and was significantly higher $(\mathrm{P}<0.05)$ than that of the ewes in the control group $(0.65 \%)$. There were no significant differences $(P>0.05)$ in the milk composition of both groups in weeks 4,6 , 8 and 10.

Percentage ash content of milk increased from $0.82 \%$ in week two of lactation to $0.99 \%$ at

Table 1

Constituent (\%) Colostrum composition of the di

\begin{tabular}{lc}
\hline Total solids & Treated \pm SEM \\
Protein & $18.34 \pm 0.34$ \\
Lactose & $5.95 \pm 0.38$ \\
Ash & $4.44 \pm 0.41$ \\
Butter fat & $0.93 \pm 0.04$ \\
Solids-non-fat & $6.86 \pm 0.14$ \\
Energy (MJ/kg) & $11.31 \pm 0.37$ \\
\hline
\end{tabular}
Control $\pm \mathrm{SEM}$

$17.3 \pm 0.21$

$5.34 \pm 0.06$

$3.78 \pm 0.10$

$0.90 \pm 0.02$

$6.89 \pm 0.20$

$10.35 \pm 0.19$

$2.63 \pm 0.08$
Significance

$*$

ns

ns

ns

ns

* ns

SEM = Standard Error of Means

$*$ = Significant at $\mathrm{P}<0.05$

NS $=$ Not Significant at $P>0.05$ 


\section{Oguike and Udeh}

Table 2: Milk Composition of the different treatment groups

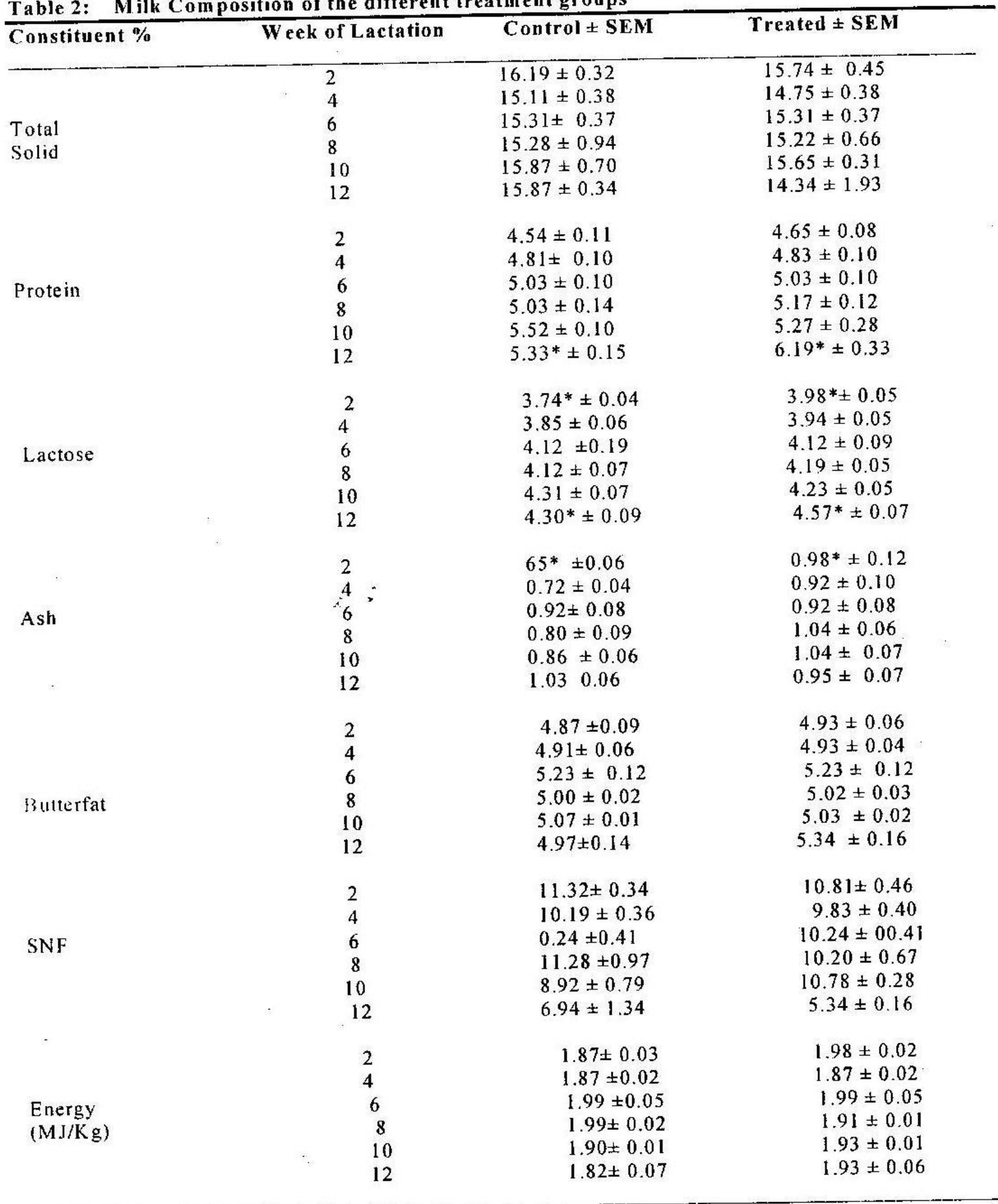

$\mathrm{SFN}=$ Solids-not-fat, *Significantly different $\mathrm{P}<0.05, \mathrm{SEM}=\mathrm{Standard}$ Error of Means 
week twelve. The numerical increases seem to agree with the findings of Ibeawuchi et al (2003) who reported progressive increase in milk ash with lactation week in goats. Ahamefule et al. (2003) also reported increase in ash content of sheep milk with increasing weeks of lactation. The significantly higher ash of the milk of the treated group implies that milk from the ewes fed $S$ mombin contain more minerals than those of the control.

At week 12 of lactation, lactose content of milk of ewes in the treated group (4.57\%), was significantly higher $(P<0.05)$ than that of the ewes in the control group (4.30\%). There was a grachal increase in lactose concentration of milk from week two to week twelve of lactation Overall mean lactose during the period of study was $4.13 \pm 0.32 \%$. This is higher than the value of $4.09,4.08$ and $4.06 \%$ reported for Vlahiko, Karagouniko andChios ewes found in Greece (Alichandis and Polychroniadou, 1996). However Peeters et al. (1992), reported mean milk lactose of $5.38 \%$ for the Texel and $5.69 \%$ for dairy milk sheep. The WAD sheep compares favourably with other exotic dairy breeds of sheep in lactose content of milk. This is of immease importance to our local dairy industries for the production of such dairy products as cheese yoghurt. Unlike protein and SNF, lactose con milk is relatively insensitive to changes ine diet of lactating animal (Foley
et al. 1972)

Prote- ant of milk of treated ewes was also signific $y$ different $(\mathrm{P}<0.05)$ from that of the control cues week 12 of lactation. The value was $6.19 \%$ as opposed to $5.33 \%$ in the control group. Milk protein increased gradually from week 2 of lactation to week 12. These increases were significantly higher at week 12 than the rest of the weeks $(\mathrm{P}<0.05)$. This trend agreed with the previous findings by Ahamefule et al (2003) and Ibeawuchi et al (2003) who also reported increases in crude protein content of milk with increase in week of lactation. Overall mean of milk protein during the study was 5.12 $\pm 0.57 \%$. This is higher than the value of $4.53 \%$ reported for the Texel ewes found in the Netherlands (Peeters et al. 1992). These disparities could be due to breed differences, environmental influences, nutrition, and/or methods of analyses. It has also been observed that milk protein content is a function of protein intake (Ibeawuchi and Akinsouyinu 1989).

Total solid was high in week 2. It however decreased by week 4 and thereafter showed a steady increase till week 10 and decreased by week 12 of lactation. This is consistent with the findings of Ibeawuchi et al. (2003) who reported steady increase in percentage total solids and subsequent decline at mid and late lactation. The overall mean of total solids was $15.48 \pm 1.78 \%$ during the period of study. This is higher than the mean of $15.36 \%$ reported for Nadji ewes in Saudi Arabia, but lower than means of $19.30 \%$ for Boutsico, $18.98 \%$ for both Attikis and Manchaga breeds, and $20.31 \%$ for Karagouniko breed of ewes (Alichandis and Polychroniadou, 1996).

The overall mean butter fat of the ewes during the study was $5.50 \pm 0.25 \%$. This value is 
considerably lower than those reported by Alichandis and Polychroniadou (1996) for the Vlahiko breed of sheep $9.05 \%$ and $8.70 \%$ for the karagouniko breed. Peeters et al., (1992) reported a value of $9.27 \%$ for Texel ewes. The low butterfat content of WAD ewes could be advantageous to the dairy industry. Fat content of milk is of interest to the consumers with concern to health and heart disease. Energy content of milk was significantly affected by week of lactation $(\mathrm{P}<0.05)$. It showed an increase from $1.88 \mathrm{MJ} / \mathrm{kg}$ in week two of lactation to 1.99 $\mathrm{MJ} / \mathrm{KG}$ by week 6 . Thereafter it declined gradually to $1.88 \mathrm{MJ} / \mathrm{kg}$ at week twelve.

Weeks of lactation affected the composition of the milk in both control and treated groups. Generally, milk protein, ash and butterfat increased from week 2 to week 12 of lactation. This finding is in agreement with the findings of several authors (Casoli et al., 1989; Dario et al., 1995; IDF, 1996; Ploumi et al., 1996) who reported increases in milk fat, protein and ash contents of milk ewes towards the end of lactation.

\section{Conclusion}

The results suggest that Spondias mombin improved the lactose, protein and ash contents of milk. It has been established that the plane of nutrition affects milk composition. Additional nutrients obtained from $S$ mombin may have been responsible for the increases observed in lactose, protein and ash content of milk from ewes fed hog plum (S.mombin). Hog plum is cheap, safe and available. It could be recommended that farmers use the leaves to feed their lactating animals.

\section{Acknowledgements}

The authors are indebted to the Head of Department of Ruminant Animal Production and Dean of College of Animal Science and Animal Production, Michael Okpara University of Agriculture Umudike, Abia State for allowing them the use of the Departmental and College facilities during the study period.

\section{References}

Ahamefule,F.O., Ibeawuchi, J.A. amd Ejiofor, C.A. (2003). A comparative study of the constituents of cattle, sheep and goat milk in a hot humid environment. Discov. Innov. 15(1/2):64-67.

Alichandis, E., and Polychroniadou, A. (1996). Special features of dairy products from ewe and goat milk from the physicochemical and organoleptic point of view. International Dairy Federation Publ., Brussels, Belgium, p. 21-43.

\section{Association of Official Analytical Chemists} (A.O.A.C 1990). Official methods of Analysis of the Association of Analytical Chemists. $19^{\text {th }}$ ed. Washington, D.C.

Burkill, I.H. (1985). The useful plants of West Tropical Africa. Vol.1. Families A-D Royal Botanic Gardens, Kew, 691 Pages. 
Casoli, C., Duranti, E., Mortbidini, L., Panella, F., and Vizioli V. (1989), Quantitative and compositional various of Massese sheep milk by parity and stage of lactation. Small Rumin. Res. 2: 47-62.

Dario, C., Laudadio, V., and Bufano, G. (1995). Characteristics of Leccess sheep: Quantitative and qualitative variations in milk during lactation. Latte 20:12661269.

Foley, R.C. Bath, D. L. Dickinson, F. N. and Tucker, H.A. (1972). Dairy cattle Principles, practices, problems profits. $1^{\text {st }}$ ed. Lea and Febiger, Philadelphia. 693 pages.

Ibeawuchi, J.A. and Akinsoyinu, A. O. (1989). Influence of brewers dry grain on the ruminant volatile fatty acid (VFA) production and milk constituents in Zebu cows. Nig. J. Anim. Prod. 21(1):1-7.

Ibeawuchi, J.A., Ahamefule, F. O. and Ringim, I.A. (2003). The influence of lactation stage on the milk constituents of Sahelian goats. Nig. J. Anim. Prod. 30 (2):259-264.

IDF (1996). Production and utilization of ewe and goat milk. International Dairy Federation Publ. Brussels. 346 pages.

M.A.F.F. (1975). Energy allowances and feeding systems for ruminants. Tech. Bull. 33 .
Ministry of Agriculture, Fisheries an Food. London.

Morton, J. (1987). Fruits of warm climates Pp245 - $248 . \quad$ http:// wwwhort.purdue.edu.newcrop/morton/ yellow mombin ars. htmI

Neville, M. C. (1995). Sampling and storage of human milk. In Handbook of Milk Composition. Jensen, R.G. (eds.). San Diego: Academic Press. Pp63-79.

Okafor, J.C. and Lamb A. (1994). Medicinal Plants used for ruminants. www faw.or/ docrep.

Oguike, M.A. and Udeh, N.E. (2008) Influence of the ethnoveterinary plant - Spondias mombin L. on partial daily milk yield $(\mathrm{pdm})$, haematology and serum biochemistry of lactating West African Dwarf (WAD) ewes. JAVA (5): 584-588.

O'Mahony, F. and Peters, K.J. (1987). Options of small holder milk processing in SubSaharan Africa: ILCA Bulletin. No 27, April, 1978. PP 2-18.

Pearsons, D (1977). The chemical Analysis of Food Chemical Publ. Coy. Inc.N. Y.

Peeters, R., Buys, N., Robijns L., Vanmonforst, D., van isterdael, J. 1992. Milk yield and milk composition of Flemish Milk sheep, 
Suffolk and Texel ewes and their crossbreds. Small Rmin. Res. 7:279-288.

Ploumi, K., Belibasaki, S., Triantaphyllidis, G. 1996. Some factors affecting daily milk yield and composition in sheep. In: proceedings, IDF Seminar, Production and Utilization of Ewe and Goat Milk, Crete, Oct. 19-20, 1995, IDF Publ,m Brssels, P.311.

1.

(Received: 18 $8^{\text {th }}$ August, 2008; Accepted 22 ${ }^{\text {nt }}$ Feb., 2009)
2.

3.

4.

5.

6.

7.

8.

9.

IC

1. 